\title{
Evaluation of Soil Cations in Agricultural Soils of East Wollega Zone in South Western Ethiopia
}

\author{
Abdenna Deressa $^{1^{\star}}$, Bikila Bote $^{2}$ and Hirpa Legesse ${ }^{3}$ \\ ${ }^{1}$ Wollega University, College of Agriculture and Natural Resource, Department of Soil Resource \\ and Watershed Management, P.O. Box 395, Nekemte, Ethiopia \\ ${ }^{2}$ Oromia Agricultural Research Institute, Nekemte Soil Research Center, P.O. Box 587, \\ Nekemte, Ethiopia \\ ${ }^{3}$ Wollega University, College of Agriculture and Natural Resource, Department of Plant Science, \\ P.O. Box 395, Nekemte, Ethiopia
}

\begin{tabular}{|c|c|}
\hline Abstract & Article Information \\
\hline The purpose of the study was to investigate the status of soil exchangeable cations, & $\begin{array}{l}\text { Article History: } \\
\text { Received : } 14-02-2013\end{array}$ \\
\hline Wollega Zone of South Western Ethiopia. A total of 353 soil samples were collected in & Revised : 28-03-2013 \\
\hline 2011and 2012 G.C from $0-20 \mathrm{~cm}$ depth. Five representative districts of East Wollega & Accepted : 30-03-2013 \\
\hline analyzed for $\mathrm{pH}$, exchangeable acidity and bases. Effective cation exchange capacity & $\begin{array}{l}\text { Keywords: } \\
\text { Aluminum }\end{array}$ \\
\hline (ECEC) was determined by summation and cations saturations were calculated. Data & Acidity \\
\hline were analyzed by SAS software. Mean soil $\mathrm{pH}$ ranged from 4.88-5.25. Mean & Calcium \\
\hline also ranged from $3.25-4.55 \mathrm{cmol}(+) / \mathrm{kg}$. Mean exchangeable magnesium and potassium & Cation saturations \\
\hline ranged from $3.02-7.66 \mathrm{cmol}(+) / \mathrm{kg}$ and $0.37-1.59 \mathrm{cmol}(+) / \mathrm{kg}$, respectively, while mean & East Wollega \\
\hline ECEC ranged from $9.81-12.88 \mathrm{cmol}(+) / \mathrm{kg}$. Acidic, basic, calcium, magnesium and & ECECE \\
\hline $\begin{array}{l}\text { potassium saturations ranged trom } 30 \\
\text { Calcium, magnesium and potassium } \mathrm{s}\end{array}$ & Magnesium \\
\hline high. Regression analysis showed soil acidity and exchangeable basic cations were & Potassium \\
\hline study soils were & *Corresponding Author: \\
\hline $\begin{array}{l}\text { marginal, respectively. However, exchangeable magnesium was rated as high. Acid } \\
\text { saturation was very high while basic cation saturations were in optimum ranges. The }\end{array}$ & Abdenna Deressa \\
\hline soils are infertile due to high acidity anc & E-mail: \\
\hline $\begin{array}{l}\text { major crops are grown in stressed soil environment. Modeling lime, calcium and } \\
\text { potassium rate for site specific recommendations and development of broad spectrum }\end{array}$ & dabdenna@yahoo.com \\
\hline $\begin{array}{l}\text { technologies such as acid tolerant crop varieties can be solutions for sustainable use of } \\
\text { soils for agriculture in East Wollega zone. }\end{array}$ & \\
\hline
\end{tabular}

\section{INTRODUCTION}

Agriculture is the mainstay of the Ethiopian economy and should provide long term food production, development and poverty alleviation (Anon., 2010). Being agrarian country, Ethiopia has faced challenge of food insecurity for the past four decades (FAO, 2001). Ethiopia is one subSaharan African country where low levels of agricultural productivity are a key cause of hunger. Decades of farming without adequate fertilizer and manure have stripped the soils of vital nutrients needed to support plant growth (IFPRI, 2010). Replenishing soil fertility is the primary biophysical requirement for increasing food production in sub-Saharan Africa countries (Sanchez, 2010). Soil is the most precious and vital natural resource and it must be managed 
Abdenna Deressa et al.,

well for sustained agricultural production (Benton, 2003). Management of cropping systems requires knowledge of physical and chemical status of soils and crops during the growing seasons for profitable production (Benton, 2003). Despite its immense contribution in agricultural production and food security, data on soil fertility in Ethiopia is largely out of date at national level, very locally specific, fragmented and difficult to access at local levels (IFPRI, 2010). For example, the last major survey of macronutrients status across the country was conducted in 1950-60's. For example, the old and out dated sweeping claim that says Ethiopian soils are least deficient in potassium could not be updated. As the result, potassium fertilization has been disregarded from national fertilizer program (Mesfin, 2007). Currently, fertilizers recommendations in Ethiopia deals with nitrogen and phosphorus dosage only and largely standard for the country disregarding the mosaic soil nature of Ethiopia.

In East Wollega zone of south western Ethiopia farmers are reporting yield decline despite application of nitrogen and phosphorus fertilizers in the form of di-ammonium phosphate and Urea. There are also reports that shows acidic cations are toxic and basic cation such as calcium, magnesium and potassium are deficient (Abdenna et al., 2007; Fite et al., Abdenna et al., 2004). Thus, this research was carried out to evaluate the current status of acidic and basic cations in East Wollega zone of south western Ethiopia.

\section{MATERIALS AND METHODS}

\section{Description of Study Location}

The study was conducted in five districts of East Wollega zone of Oromia National Regional State of Ethiopia. These were Guto Gida, Gida Ayana, Kiremu, Sasiga and Diga districts. The districts are representative of the remaining districts and selected purposively. The ten years

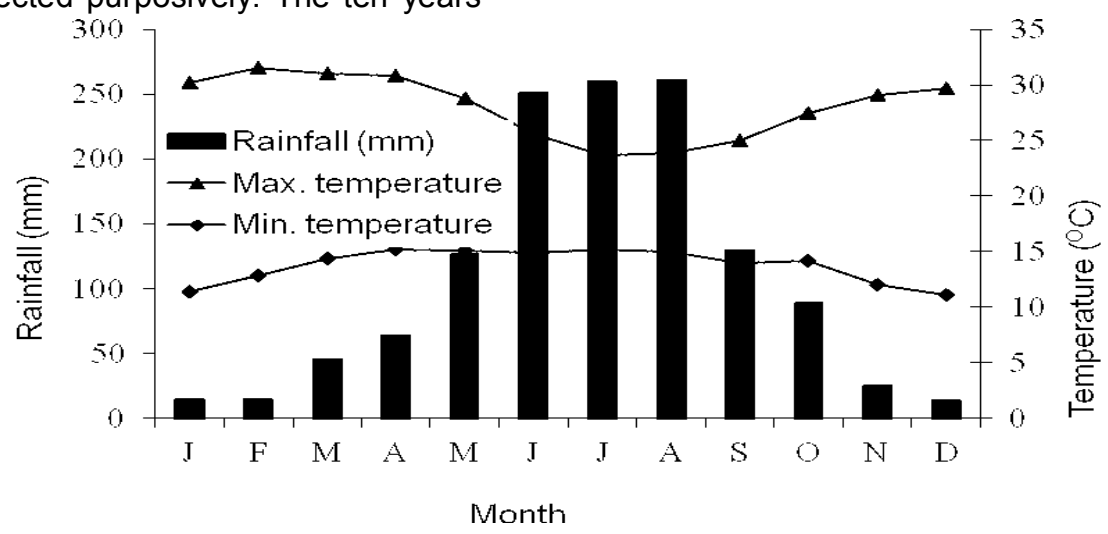

Figure1: Mean monthly rainfall and mean maximum and minimum temperatures of Nekemte Metrological
Station.

Figure1: Mean monthly rainfall and mean maximum and minimum temperatures of Nekemte Metrological
Station.

Sci. technol. arts Res. J., Jan-Mar 2013, 2(1): 10-17

(1996-2007) climatic data from Nekemte Meteorological Station recorded an average annual rainfall $1780 \mathrm{~mm}$ which is characterized by mono modal rainfall pattern and its annual mean minimum and maximum monthly temperatures lies between 13.75 and $27.65^{\circ} \mathrm{C}$ (Figure. 1). The topography of the study area is undulating. According to FAO (1990) soil classification system, the soil class of the study zone is dystric Nitisols. The livelihoods of the rural communities of the study districts depend mainly on crop production, animal husbandry and mixed farming systems. The major crops of the areas are coffee, maize, sorghum, teff, wheat, barley, sesame, finger millet, haricot bean, faba bean, field pea and lima bean.

\section{Soil Sampling and Analysis}

A total of three hundred fifty three soil samples were collected from 0 to $20 \mathrm{~cm}$ depth by auger from farmers' field in 2011/2012. Composite samples were collected from uniform farmers' field, standard sampling techniques and sample preparation procedures were followed. During sampling the farmers were asked to mention the type of crops they grow in the parcel of farmland in next cropping season. The samples were transported to Nekemte soil research center for laboratory analysis. Soil $\mathrm{pH}$ was determined in soil to water ratio of 1:2.5 (w/v). Exchangeable bases $(\mathrm{Ca}, \mathrm{Mg}, \mathrm{Na}$, and $\mathrm{K})$ were extracted with $1 \mathrm{M}$ ammonium acetate at $\mathrm{pH}$ 7. $\mathrm{Ca}$ and $\mathrm{Mg}$ were analyzed by titrations using EDTA method. Exchangeable $\mathrm{K}$ and Na were measured by flame photometer. Exchangeable acidity was determined by saturating the samples with $1 M$ $\mathrm{KCl}$ solution and titrated with sodium hydroxide as described by McLean (1965). ECEC was determined by summation of exchangeable bases and exchangeable acidity (Chapman, 1965). Descriptive statistics and correlation analysis were carried out using SAS software version 9.01 (SAS, 2004). 


\section{RESULTS AND DISCUSSIONS}

Soil $\mathrm{pH}$, exchangeable acidity, exchangeable calcium, exchangeable magnesium, exchangeable potassium and ECEC of samples from five districts of East Wollega zone of Ethiopia are presented in Table 2. The distributions of soil $\mathrm{pH}$ in these districts are indicated in Figure 2. The mean soil pH of Diga, Gida Ayana, Guto Gida, Kiremu and Sasiga districts are 5.24, 5.01, 4.88, 5.05 and 4.89, respectively. According to Hazelton and Murphy (2007), Donald (2003) and Benton (2003) the mean soil $\mathrm{pH}$ of Sasiga and Guto Gida districts are categorized or rated as very strongly acidic while mean soil pH of Diga, Kiremu and Gida Ayana districts are rated as strongly acidic. These results are in agreement with reports of Achalu et al. (2012), Abdenna et al. (2007), Fite et al. (2007), and Mesfin (2007). Soil pH is probably the most important master chemical soil parameter and it reflects the overall chemical status of the soil and influences a whole range of chemical and biological processes occurring in the soils (Bloom 2000). Most plants and soil organisms prefer $\mathrm{pH}$ range between 6.0 and 7.5 (Hall 2008; Hazelton and Murphy 2007). The results obtained from the different districts of East Wollega zones showed that the $\mathrm{pH}$ of the soils is out of this normal $\mathrm{pH}$ range. Under such low $\mathrm{pH}$ the availability of essential nutrients are critically affected. Toxicity of aluminum to plants greatly affects root and shoot growth as well as nutrients and water absorption. Moreover, the activities of microorganisms which play pivotal roles in nutrient cycling in agro ecosystems are affected.

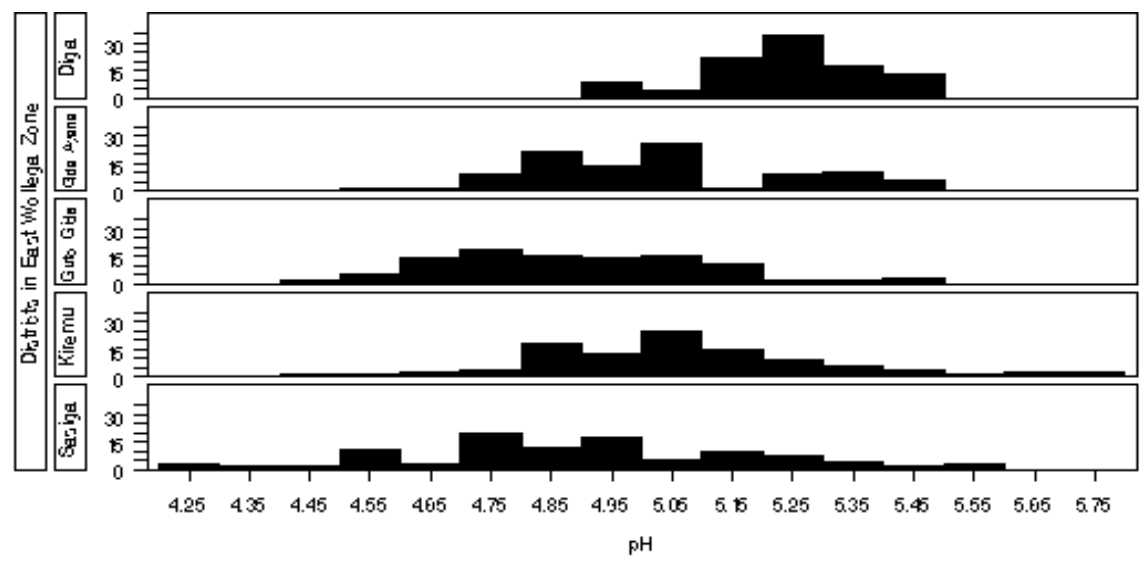

Figure 2: Frequency distribution of soil $\mathrm{pH}\left(\mathrm{H}_{2} \mathrm{O}\right)$ in five districts from East Wollega Zone of Ethiopia.

The mean soil exchangeable acidity of Diga, Gida Ayana, Guto Gida, Kirem and Sasiga districts are $3.70,4.55,4.71,3.41$ and 3.25 $\mathrm{cmol}(+) / \mathrm{kg}$, respectively (Table 2 ). There is considerable variation among samples in exchangeable acidity within and among districts and the distributions of soil exchangeable acidity in these districts are indicated in Figure 3. This variation in exchangeable acidity may be due variation in soil $\mathrm{pH}$, soil organic matter, soil texture and cropping history.

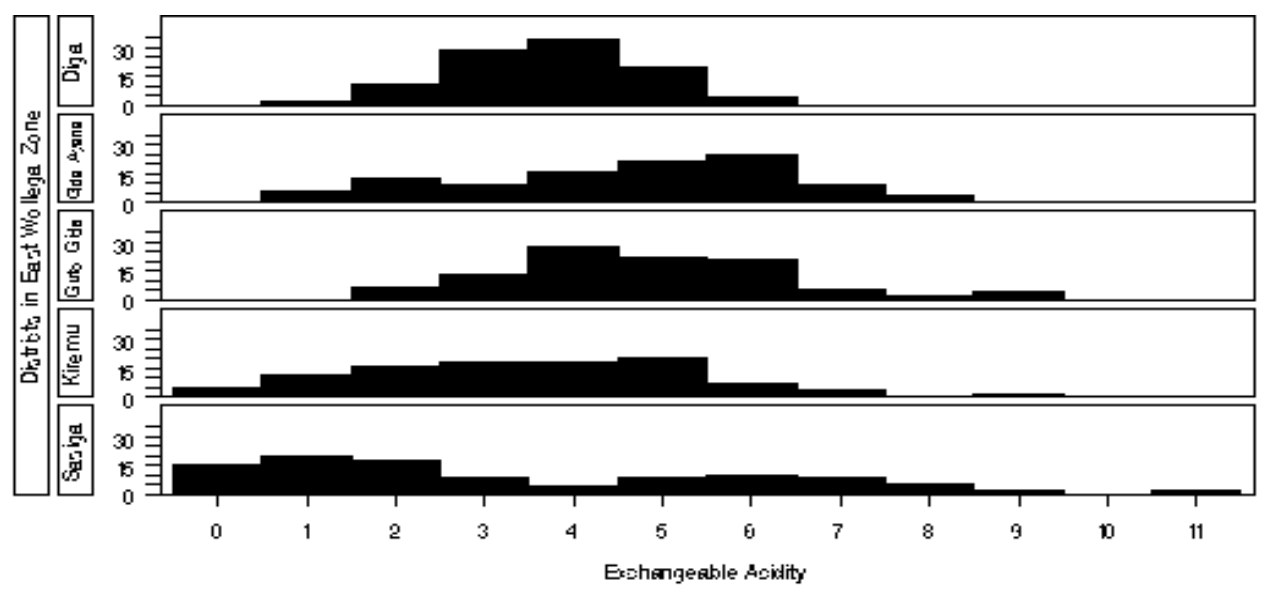

Figure 3: Frequency distribution of soil exchangeable acidity $(\mathrm{cmol} / \mathrm{kg})$ in five districts from East Wollega Zone of Ethiopia. 
Abdenna Deressa et al.,

According to Hazelton and Murphy (2007) and Moore (2001) the mean exchangeable acidity in all study districts are categorized or rated as very high. Moreover, correlation analysis indicated that soil $\mathrm{pH}$, exchangeable acidity, exchangeable calcium, exchangeable magnesium and ECEC are correlated significantly (Table 1 ). This finding is in agreement with Lindsay (1996) and Moore (2001), who reported that the solubility of $\mathrm{Al}$ containing minerals increase as the soil $\mathrm{pH}$ falls
Sci. technol. arts Res. J., Jan-Mar 2013, 2(1): 10-17

below 5.5 and suggested that the probability of $\mathrm{Al}$ toxicity to plants become higher. Mean exchangeable acid saturation percentage of study soils ranged from 30 to $43 \%$ (Table 2). Maize and sorghum show toxicity symptom of acidity at $20 \%$ acid saturation (Fageria and Baligar, 2003) indicating that these major crops are growing under suboptimal soil conditions in East Wollega zone.

Table 1: Pair-Wise Pearson Correlation Coefficient of soil parameters of soils from East Wollega Zone of Ethiopia

\begin{tabular}{|c|c|c|c|c|c|c|}
\hline Parameters & $\mathrm{pH}$ & $\begin{array}{c}\text { Exchangeable } \\
\text { acidity }\end{array}$ & $\begin{array}{c}\text { Exchangeable } \\
\mathrm{Ca}\end{array}$ & $\begin{array}{c}\text { Exchangeable } \\
\mathrm{Mg}\end{array}$ & $\begin{array}{c}\text { Exchangeable } \\
\mathrm{K}\end{array}$ & ECEC \\
\hline $\mathrm{pH}$ & 1.00 & & & & & \\
\hline $\begin{array}{l}\text { Exchangeable } \\
\text { acidity }\end{array}$ & $-0.55^{\star *}$ & 1.00 & & & & \\
\hline Exchangeable $\mathrm{Ca}$ & $0.45^{\star *}$ & $-0.51^{* *}$ & 1.00 & & & \\
\hline Exchangeable $\mathrm{Mg}$ & $0.33^{\star *}$ & $-0.54^{\star *}$ & $0.56^{* *}$ & 1.00 & & \\
\hline Exchangeable $\mathrm{K}$ & $0.15^{\star *}$ & $-0.12^{*}$ & $0.26^{* *}$ & $0.014^{\mathrm{ns}}$ & 1.00 & \\
\hline ECEC & $0.11^{*}$ & $0.11^{* *}$ & $0.72^{\star \star}$ & $0.37^{* *}$ & $0.53^{\star *}$ & 1.00 \\
\hline
\end{tabular}

Table 2: Analysis of Soil for $\mathrm{pH}$, exchangeable acidity, exchangeable calcium, exchangeable magnesium and exchangeable potassium in five districts of East Wollega Zone of Ethiopia

\begin{tabular}{|c|c|c|c|c|c|}
\hline \multicolumn{6}{|c|}{ Soil pH $\left(\mathrm{H}_{2} \mathrm{O}\right)$} \\
\hline Districts & $\mathbf{N}^{*}$ & Mean & Std. Dev & Minimum & Maximum \\
\hline Diga & 46 & 5.24 & 0.13 & 4.91 & 5.49 \\
\hline Gida Ayana & 57 & 5.01 & 0.22 & 4.58 & 5.44 \\
\hline Guto Gida & 77 & 4.88 & 0.22 & 4.47 & 5.48 \\
\hline Kiremu & 101 & 5.05 & 0.23 & 4.48 & 5.75 \\
\hline Sasiga & 72 & 4.89 & 0.28 & 4.28 & 5.55 \\
\hline \multicolumn{6}{|c|}{ Exchangeable Acidity $(\mathrm{Al}+\mathrm{H}), \mathrm{cmol}(+) / \mathrm{kg}$} \\
\hline Diga & 46 & 3.70 & 1.21 & 1.10 & 6.30 \\
\hline Gida Ayana & 57 & 4.55 & 1.75 & 1.00 & 7.70 \\
\hline Guto Gida & 77 & 4.71 & 1.54 & 1.80 & 8.90 \\
\hline Kiremu & 101 & 3.41 & 80 & 0.10 & 8.50 \\
\hline Sasiga & 72 & 3.25 & 2.74 & 0.10 & 10.90 \\
\hline \multicolumn{6}{|c|}{ Exchangeable calcium, $\mathrm{cmol}(+) / \mathrm{kg}$} \\
\hline Diga & 46 & 3.70 & 1.21 & 1.10 & 6.30 \\
\hline Gida Ayana & 57 & 4.55 & 1.75 & 1.00 & 7.70 \\
\hline Guto Gida & 77 & 4.71 & 1.54 & 1.80 & 8.90 \\
\hline Kiremu & 101 & 3.41 & 1.80 & 0.10 & 8.50 \\
\hline Sasiga & 72 & 3.25 & 2.74 & 0.10 & 10.90 \\
\hline \multicolumn{6}{|c|}{ Exchangeable magnesium, $\mathrm{cmol}(+) / \mathrm{kg}$} \\
\hline Diga & 46 & 3.67 & 1.46 & 0.80 & 6.60 \\
\hline Gida Ayana & 57 & 4.17 & 1.74 & 1.20 & 9.25 \\
\hline Guto Gida & 77 & 3.02 & 0.84 & 1.30 & 5.90 \\
\hline Kiremu & 101 & 7.66 & 3.01 & 2.50 & 17.15 \\
\hline Sasiga & 72 & 5.88 & 3.36 & 1.55 & 12.80 \\
\hline \multicolumn{6}{|c|}{ Exchangeable potassium, $\mathrm{cmol}(+) / \mathrm{kg}$} \\
\hline Diga & 46 & 0.92 & 1.00 & 0.16 & 3.87 \\
\hline Gida Ayana & 57 & 0.81 & 0.58 & 0.25 & 2.11 \\
\hline Guto Gida & 77 & 1.59 & 1.59 & 0.00 & 8.8 \\
\hline Kiremu & 101 & 0.91 & 0.69 & 0.19 & 3.12 \\
\hline Sasiga & 72 & 0.37 & 0.34 & 0.06 & 1.71 \\
\hline \multicolumn{6}{|c|}{ ECEC, $\mathrm{cmol}(+) / \mathrm{kg}$} \\
\hline Diga & 46 & 12.52 & 3.97 & 6.67 & 19.77 \\
\hline Gida Ayana & 57 & 10.78 & 1.55 & 6.45 & 13.93 \\
\hline Guto Gida & 77 & 12.88 & 2.12 & 9.63 & 20.98 \\
\hline Kiremu & 101 & 11.98 & 2.56 & 7.89 & 22.67 \\
\hline Sasiga & 72 & 9.81 & 2.91 & 5.25 & 22.80 \\
\hline
\end{tabular}


Abdenna Deressa et al.,

The mean soil exchangeable calcium of Diga, Gida Ayana, Guto Gida, Kiremu and Sasiga districts are $3.70,4.55,4.71,3.41$ and 3.25 $\mathrm{cmol}(+) / \mathrm{kg}$ (Table 3 ) respectively. The mean exchangeable magnesium of Diga, Gida Ayana, Guto Gida, kiremu and Sasiga districts are 3.67, $4.17,3.02,7.66, \& 5.88 \mathrm{cmol}(+) / \mathrm{kg}$, respectively (Table 2). The distributions of exchangeable calcium and magnesium in these districts are indicated in Figure $4 \& 5$ respectively. According to Hazelton and Murphy (2007) exchangeable calcium is categorized or rated as low. This indicates that more calcium is required as production input \& the response to calcium application in form of fertilizer more likely increase productivity. According to the Benton (2003), the exchange-able magnesium in these soils are categorized as high which implies that returns are less likely optimized with additions of magnesium as external inputs in the form of fertilizers. More over the basic cation saturations in study zone ranged from medium to high. The mean effective cation exchange capacity of Diga, Gida Ayana, Guto Gida, Kiremu \& Sasiga districts are $12.52,10.78,12.88,11.98 \& 9.81 \mathrm{cmol}(+) / \mathrm{kg}$, respectively (Table 2 ) and the distributions of effective cation exchange capacity of soils in these districts are indicated in Figure 6. According to Moore (2001) and Benton (2003), the effective cation exchange capacity of these soils is categorized as medium to high.
Sci. technol. arts Res. J., Jan-Mar 2013, 2(1): 10-17

The mean soil exchangeable potassium of Diga, Gida Ayana, Guto Gida, Kiremu and Sasiga districts are $0.92,0.82,1.59,0.92$, and $0.37 \mathrm{cmol}$ $(+) / \mathrm{kg}$ (Table 3 ) respectively. Distributions of exchangeable potassium in these districts are indicated in Figure 7. According to Moore (2001), the mean soil exchangeable potassium is rated as low to moderate except in soils from Guto Gida districts. This shows that application of potassium containing fertilizers can increase production and productivity in study zone. However, because of limited knowledge on the potassium dynamics in Ethiopian soils and absence of a remarkable response to potassium application in the central and northern part of the country, there has been sweeping generalization on potassium status in Ethiopian soils and as a result there has not been adequate focus to potassium in the national fertilizer scheme (Mesfin 2007). This finding reveals that western Ethiopian soils are not rich in potassium and disproves the old age sweeping generalization that says Ethiopian soils are rich in potassium. This finding also emphasizes that enhancing potassium fertilization research particularly in high rainfall, acidic and productive region of south and south western Ethiopia is vital which is as equal as other essential primary nutrients in achieving food security.

Table 3: Exchangeable cation saturation percentage in five districts of East Wollega Zone of Ethiopia.

\begin{tabular}{|c|c|c|c|c|c|}
\hline \multicolumn{6}{|c|}{ Exchangeable acid saturation (in percentage) } \\
\hline Districts & $\mathbf{N}^{*}$ & Mean & Std Dev & Minimum & Maximum \\
\hline Diga & 46 & 32 & 11 & 6 & 55 \\
\hline Gida Ayana & 57 & 43 & 17 & 9 & 74 \\
\hline Guto Gida & 77 & 37 & 11 & 10 & 64 \\
\hline Kiremu & 101 & 30 & 17 & 1 & 70 \\
\hline Sasiga & 72 & 34 & 26 & 1 & 80 \\
\hline \multicolumn{6}{|c|}{ Exchangeable base saturation percentages } \\
\hline Diga & 46 & 68 & 11 & 45 & 94 \\
\hline Gida Ayana & 57 & 57 & 17 & 26 & 91 \\
\hline Guto Gida & 77 & 63 & 11 & 36 & 90 \\
\hline Kiremu & 101 & 70 & 17 & 30 & 99 \\
\hline Sasiga & 72 & 66 & 26 & 20 & 99 \\
\hline \multicolumn{6}{|c|}{ Exchangeable Calcium saturation percentages } \\
\hline Diga & 46 & 62 & 10 & 41 & 82 \\
\hline Gida Ayana & 57 & 50 & 15 & 23 & 84 \\
\hline Guto Gida & 77 & 52 & 10 & 32 & 77 \\
\hline Kiremu & 101 & 62 & 15 & 27 & 96 \\
\hline Sasiga & 72 & 62 & 27 & 16 & 97 \\
\hline \multicolumn{6}{|c|}{ Exchangeable magnesium saturation percentages } \\
\hline Diga & 46 & 29 & 6 & 8 & 41 \\
\hline Gida Ayana & 57 & 39 & 16 & 11 & 79 \\
\hline Guto Gida & 77 & 24 & 6 & 11 & 37 \\
\hline Kiremu & 101 & 62 & 15 & 27 & 96 \\
\hline Sasiga & 72 & 60 & 28 & 16 & 97 \\
\hline \multicolumn{6}{|c|}{ Exchangeable potassium saturation percentages } \\
\hline Diga & 46 & 6 & 5 & 2 & 20 \\
\hline Gida Ayana & 57 & 8 & 5 & 2 & 19 \\
\hline Guto Gida & 77 & 11 & 9 & 0 & 48 \\
\hline Kiremu & 101 & 7 & 5 & 2 & 23 \\
\hline Sasiga & 72 & 4 & 3 & 0 & 17 \\
\hline
\end{tabular}




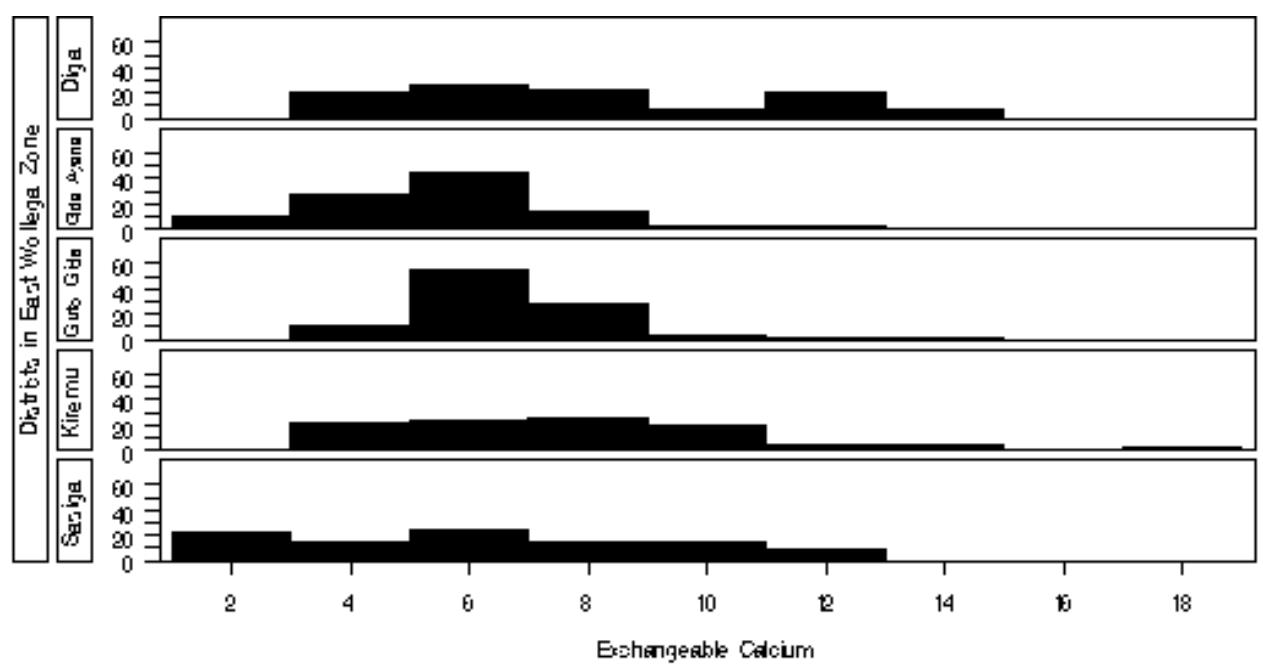

Figure 4: Frequency distribution of soil exchangeable calcium $(\mathrm{cmol} / \mathrm{kg})$ in five districts from East Wollega Zone of Ethiopia.

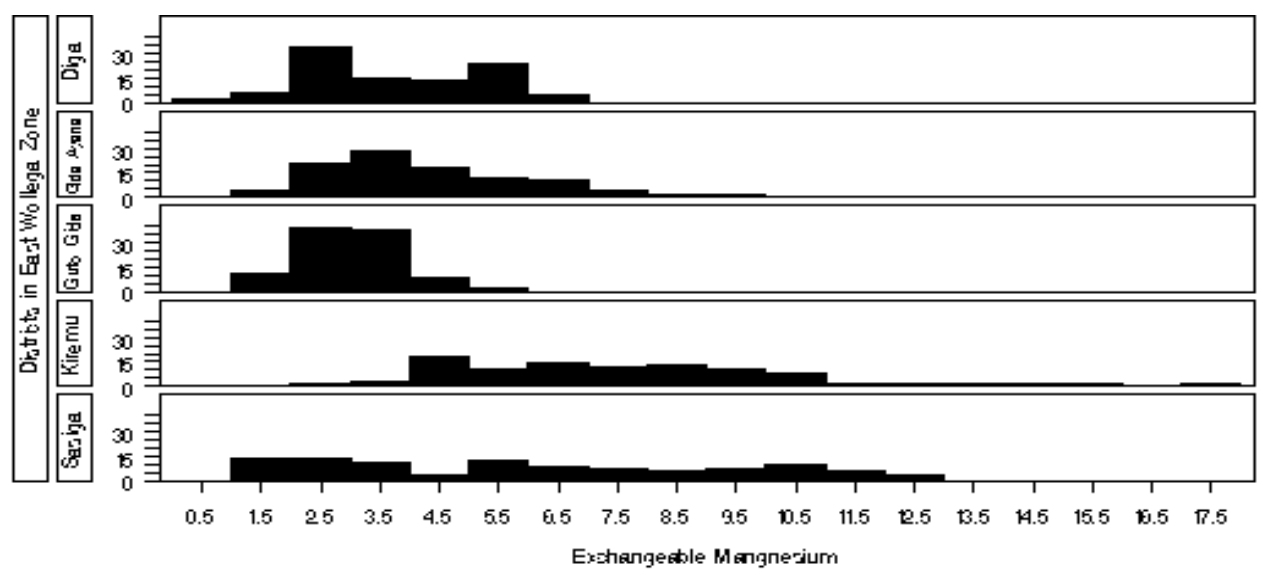

Figure 5: Frequency distribution of soil exchangeable magnesium $(\mathrm{cmol} / \mathrm{kg})$ in five districts from East Wollega Zone of Ethiopia.

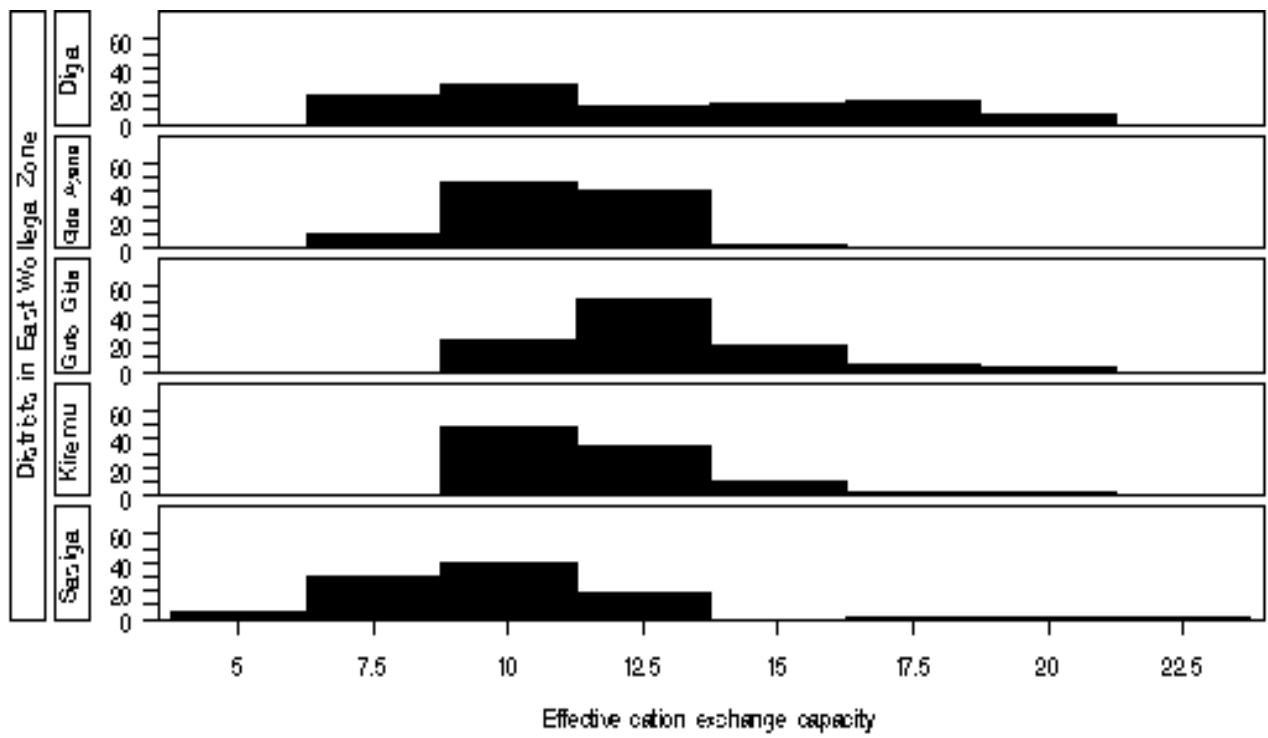


Figure 6: Frequency distribution of soil effective cation exchange capacity $(\mathrm{cmol} / \mathrm{kg})$ in five districts from East Wollega Zone of Ethiopia.

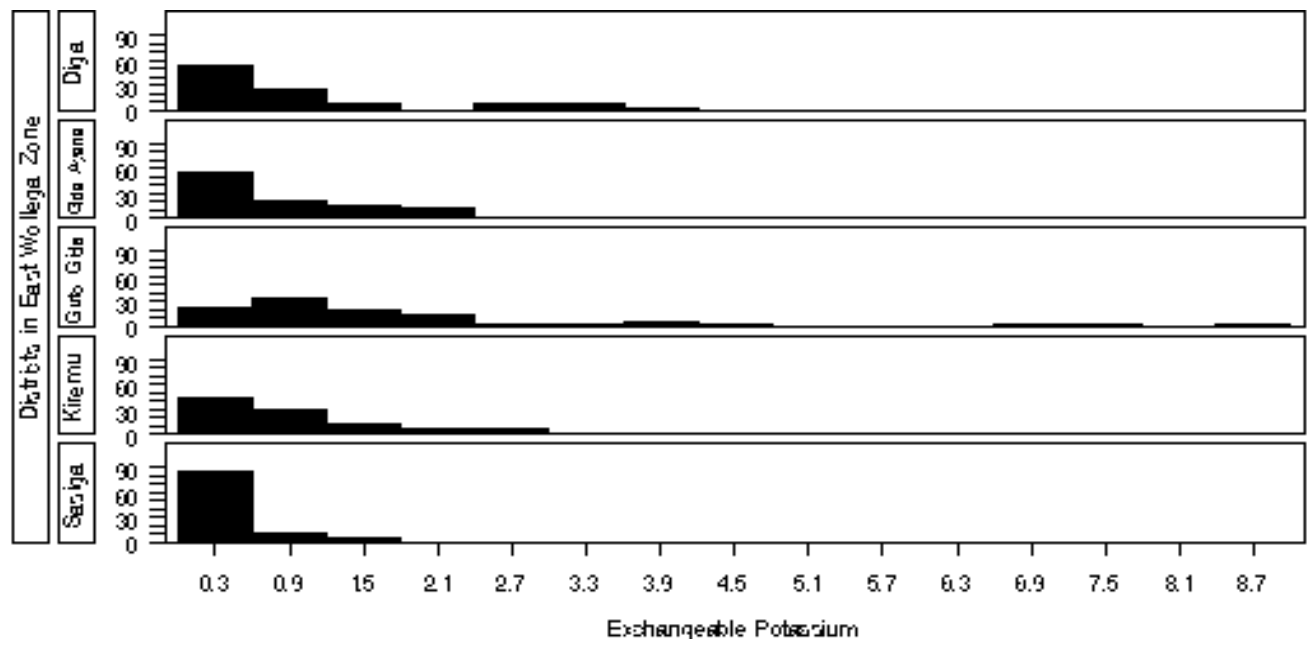

Figure 7: Frequency distribution of soil exchangeable potassium $(\mathrm{cmol} / \mathrm{kg})$ in five districts from East Wollega Zone of Ethiopia.

\section{CONCLUSIONS}

Soils of Guto Gida, Diga, Sasiga, Gida Ayana and Kiremu districts of East Wollega zone of Oromia National Regional State in Western Ethiopia are very strongly to strongly acidic. The soils have extremely high acid saturation and the soil reactions are not suitable for most agricultural crop productions. This study also revealed that soils of East Wollega zone are deficient in exchangeable calcium and exchangeable potassium ranges from low to marginal. Under these extreme acidic soil conditions, the major crops of East Wollega zone such as maize and sorghum are growing under suboptimal soil conditions. In order to achieve food security the region through increased production and productivity of these acidic soils, fertilizing the soils with potassium and calcium is a necessity. Moreover, ameliorating these acidic soils with inorganic lime to increase calcium contents and soil $\mathrm{pH}$, and organic amendments which complexes or arrest toxic aluminum are of greatest significance. Thus, soil fertility research in south western Ethiopia should gear towards site specific fertilizer recommendation such modeling lime, potassium and calcium fertilizer rates alone or in association with other primary essential nutrients. In addition, research should focus on improving crop genetics for tolerance to soil acidity and Al toxicity which can be complementary to or independent of soil liming.

\section{REFERENCES}

Abdenna Deressa, Wakene Negassa Chewaka, and Tilahun Geleto. (2007). Inventory of soil acidity status in crop lands of central \& western Ethiopia, utilization of diversity in land use systems Sustainable and organic approaches to meet Human needs, Witzenhausen, 9-11, October, 2007.

Abdenna Deressa., Wakene Negassa., Fite Getaneh and Birhanu Dinsa. (2004). Response of tef to nitrogen and phosphorus fertilizers under farmers' conditions. A paper presented on the Conference of the Crop Science Society of Ethiopia, 11, Addis Abeba (Ethiopia), 26-28 Apr 2004. Publisher, Crop Science Society of Ethiopia, Addis Abeba (Ethiopia), May 2006.

Achalu Chimdi, Heluf Gebrekidan, Kibebew Kibret, and Abi Tadesse. (2012). Status of selected physicochemical properties of soils under different land use systems of Western Oromia, Ethiopia. Journal of Biodiversity and Environmental Sciences, 2(3), 57-71.

Anonymous. (2010). Accelerating Ethiopian Agriculture Development for Growth, Food Security and Equity. Synthesis of findings and recommendations for the implementation of diagnostic studies in extension, irrigation, soil health/fertilizer, rural finance, seed systems, and output markets (maize, pulses, and livestock)

Benton and Jones J. (2003). Agronomic handbook: Management of crops, soils, and their fertility. CRC Press LLC, 2000 N.W. Corporate Blvd., Boca Raton, Florida 33431. Pp 482. 
Bloom, P.R. (2000). Soil pH and pH buffering. In: ME Sumner, ed. Handbook of Soil Science. Boca Raton, FL: CRC Press, 2000, pp B333-B352.

Chapman, H. D. (1965). Cation exchange capacity. In: C.A. Black (ed.) Methods of Soil Analysis Part II, pp. 891-901. Agronomy series number 9, American Society of Agronomy, Madison, Wisconsin.

Donald, L. Sparks. (2003). Environmental Soil Chemistry. Second Edition. University of Delaware, Academic Press, An imprint of Elsevier Science, Pp 367, http://www.academicpress.com.

Fageria, Nand, and Virupax C. Baligar. (2003). Fertility Management of Tropical Acid Soils for Sustainable Crop Production. In: Zdenko Rengel (ed.) Handbook of Soil Acidity. University of Western Australia, Perth, Western Australia, Australia.

FAO (Food and Agricultural Organization of the United Nations). (2001). Soil fertility management in support of food security in sub-saharan africa. Food and Agriculture Organization of the NnitedNations. Rome, 2001.

FAO. (1990). Soil Map of the World: Revised legend FAO (Food and Agriculture Organization), Rome, Italy.

Fite Getaneh, Abdenna Deressa, Wakene Negassa Chewaka. (2007). Influence of Irrigation on Soil Chemical Properties. In: "Utilization of diversity in land use systems: Sustainable and organic approaches to meet human needs". A paper presented on Tropentag 2007, October 9-11, 2007 Witzenhausen, Germany.

Hall and Roger Elliot. (2008). Soil essentials: Managing your farm's primary asset. Australia, BPA Print Group. Pp. 191.
Hazelton Pam and Brian Murphy. (2007). Interpreting Soil Test Results. What Do All the Numbers Mean? Published by CSIRO Publisjing.160 Pp.

IFPRI (International Food and Policy Research Institute) (2010). Fertilizer and Soil Fertility Potential in Ethiopia. Constraints and opportunities for enhancing the system.

Lindsay, W.L., Walthall, P.M. (1996). The solubility of aluminum in soils. In: G Sposito, ed. The Environmental Chemistry of Aluminum. Boca Raton, FL: CRC Press, 1996, pp 333-361.

McLean, E.O. (1965). Aluminum. In: C.A. Black (Ed.). Methods of Soil Analysis. Agronomy Series No. 9. Part II. pp. 978-998. American Society of Agronomy, Madison, Wisconsin, USA.

Mesfin Abebe. (2007). Nature and Management of Acid Soils in Ethiopia.

Moore., Geoff. (2001). Soil Guide: A Hand Book For Understanding and Managging Agricultural Soils. Compiled And Edited By Geoff Moore, Bulletin 4343, July 2001.

Murray, B and McBride. (1994). Environmental chemistry of soils. New York, Oxford University Press, Pp 441.

Ridley, W.J., Slattery, K.R., Helyar, A., Cowling. (1990). The importance of the carbon cycle to acidification of a grazed annual pasture. Australian Journal of Experimental Agriculture, 30, 529-537.

Sanchez Pedro. (2010). Tripling Crop Yields in Tropical Africa. Nature geosciences, Vol 3, Commentary Focus. www.nature.com/naturegeoscience

SAS Institute inc. (2004). SAS/STAT Guide: version 9.1, SAS Institute Inc, Cam, North Carolina. 